\title{
Relationships between hydraulic traits and habitat preference for six Acer species occurring in the French Alps
}

\author{
Jérôme TISSIER ${ }^{\mathrm{a}}$, Luc LAMBS ${ }^{\mathrm{b}}$, Jean-Paul PELTIER ${ }^{\mathrm{a}}$, Gérard MARIGO ${ }^{\mathrm{a} *}$ \\ a Laboratoire d'Écologie Alpine, Université Joseph Fourier, BP 53, 38041 Grenoble Cedex 9, France \\ ${ }^{\mathrm{b}}$ Centre d'Écologie des Systèmes Aquatiques Continentaux, 29 rue Marvig, 31055 Toulouse Cedex 04, France
}

(Received 23 October 2002; accepted 11 April 2003)

\begin{abstract}
Xylem hydraulic properties and vulnerability to cavitation were studied in six Acer species which occur, in the French Alps, along a soil moisture gradient from the moist valleys to the drier mountain stands. The results obtained suggest that a relationship existed between hydraulic properties and the species moisture preference. Maples located in dry zones (A. opalus, A. monspessulanum) proved more resistant to drought-induced cavitation than species that occurred in an irrigated area (A. negundo, A. pseudoplatanus, A. platanoides, A. campestre). The most vulnerable species to cavitation (A. negundo, A. pseudoplatanus, A. platanoides, A. campestre) showed the highest hydraulic conductances, whereas more cavitation-resistant species (A. opalus, A. monspessulanum) had the lowest conductances. This suggests a tradeoff between hydraulic efficiency and cavitation vulnerability. The possible ecological significances of these data are discussed in relation to the distribution of Acer species in their natural habitats.
\end{abstract}

drought tolerance / hydraulic conductance / xylem cavitation / Acer species

Résumé - Étude des relations entre les caractéristiques hydrauliques et les exigences écologiques de six espèces d'Acer dans les Alpes françaises. Les propriétés hydrauliques du xylème et la vulnérabilité à la cavitation ont été étudiées chez six espèces d'Acer qui se distribuent, dans les Alpes françaises, selon un gradient d'exigence hydrique depuis les vallées humides jusqu'à des zones plus sèches de moyenne montagne. Les résultats obtenus suggèrent l'existence d'une relation entre les propriétés hydrauliques et le gradient d'exigence hydrique des différentes espèces d'Acer. Les érables situés dans les zones sèches (A. opalus, A. monspessulanum) sont plus résistants à la cavitation que ceux implantés dans les stations bien alimentées en eau (A. negundo, A. pseudoplatanus, A. platanoides, A. campestre). De plus, les espèces les plus vulnérables à la cavitation (A. negundo, A. pseudoplatanus, A. platanoides, A. campestre) possèdent les conductances hydrauliques les plus élevées et inversement pour les espèces les moins sensibles (A. opalus, A. monspessulanum). Ceci suggère l'existence d'un « trade-off » entre efficience hydraulique et vulnérabilité à la cavitation. Ces résultats sont analysés au plan écologique en relation avec le mode de distribution des différentes espèces dans leur environnement respectif.

tolérance à la sécheresse / conductance hydraulique / cavitation du xylème / Acer species

\section{INTRODUCTION}

Terrestrial plants depend a great deal on the transport of water from the soil through the plant. Water availability is one of the most important factors which influence not only the growth and development of plants, but also the spatial distribution of species in their appropriate habitat $[1,11]$. Cyclic droughts favour the establishment of species which are able to acclimate to water deficit, and tend to eliminate species that are not able to do so.

There is ample evidence indicating that plant hydraulic conductance is limited by drought and freezing stress, thus restricting their water balance, their gas exchange, and their growth [6,30]. An important component of hydraulic architecture is the vulnerability to drought-induced xylem cavitation.
Cavitation is the abrupt change from liquid water under tension to water vapor resulting, when xylem tension exceeds a critical value, in the breakage of the water column $[6,22,26$, $28,32]$. It has been suggested that xylem vulnerability to cavitation may be the most important character determining drought tolerance in plants [30]. Catastrophic xylem dysfunction occurring through the entire xylem results in the death of the plant [29]. Consequently, studying the differences in the hydraulic architecture, such as hydraulic conductance and vulnerability to cavitation of plants, may help us to understand species habitat preferences with regard to water availability in soils.

It had been suggested that there is a trade-off between the xylem hydraulic conductance and the xylem vulnerability to cavitation [32]. This trade-off hypothesis was based on the

* Corresponding author: gerard.marigo@ujf-grenoble.fr 
assumption that wider conduits were more vulnerable to water stress-induced cavitation. This hypothesis remains controversial since other studies have shown that vulnerability to drought-induced cavitation is not related to conduit diameters but rather to the structural properties of the interconduit pit membranes [1, 21, 28]. Thus both the existence of and lack of a trade-off between xylem conductance and vulnerability to cavitation have been documented.

In this study, we concentrated on certain coexisting species from the highly diverse genus Acer, with respect to their spatial distribution in the French Alps. These species are distributed along an ecological gradient from the moist alpine valleys to the drier low mountains in relation to their water consumption $[23,24]$. They were selected because they are representative of different levels of adaptation to drought, ranging from species well adapted to drought such as Acer monspessulanum L. and Acer opalus Mill., to water-demanding species such as A. negundo L. and A. pseudoplatanus L. Some properties of the hydraulic system, the hydraulic conductance and the vulnerability to cavitation, were characterized to determine if species with different habitat preferences had different hydraulic characteristics, and also to see if differences in hydraulic architecture between species might explain the habitat preferences. The hypothesis was that species found in drier habitats would be more resistant to water stress-induced cavitation than species restricted to wet sites. In conjunction with this hypothesis, this study also attempts to verify, for this group of closely related species, the existence (or not) of a trade-off between xylem conductance and xylem vulnerability to cavitation.

\section{MATERIALS AND METHODS}

\subsection{Study site and plant material}

Measurements were made in June and July 2000 and 2001 on six species of Acer growing in their natural habitat on two different sites. The first site, which is located along the Isere river, on the Campus of the University of Grenoble ( $45^{\circ} 20^{\prime} \mathrm{N}, 5^{\circ} 30^{\prime}$ E, elevation $200 \mathrm{~m}$ ), is well-watered [17]. A. negundo, A. pseudoplatanus, A. platanoides L., A. campestre L. (10-15 years old, $10 \mathrm{~m}$ tall) occur in this place, mixed with other co-existing tree species (Tilia cordata Mill.), on an alluvial soil with a water table at a depth of between 2.20 and $2.50 \mathrm{~m}$, on average. Some experiments were also performed on a A. monspessulanum species which was cultivated at the arboretum of the Campus. The other site, known as "La Bastille", is located in a low mountain stand in the extern zone of the North-western Alps $\left(45^{\circ} 12^{\prime}\right.$ N, $5^{\circ} 44^{\prime}$ E, elevation $800 \mathrm{~m}$ ). This site is characterized by relative dry conditions. Vegetation, soil and climate have been described in detail by Manneville [16]. In this area, the coarse texture (limestone bedrock outcrops) explains the dryness of the soil and in summer, with the lack of rainfall, this site is subjected, periodically, to drought [16]. The location was characterized by the presence of Acer opalus and Acer monspessulanum, in association with Fraxinus excelsior L. and despite the unfavourable environmental dry conditions for its growth, some trees of A. pseudoplatanus were also present here. However, compared to the alluvial floodplains, the size of maple trees present on the dry sites is smaller (4-6 m). All trees examined were approximately 12 years old. In most of the experiments carried out in the stations, three to four trees per species were studied for each population.

\subsection{Hydraulic conductivity analysis}

Xylem hydraulic efficiency was determined on 1-year-old twigs from branches collected with a pruning-scissors in the morning (between 7 and $8 \mathrm{~h}$, solar time) from mature trees. The branches were enclosed in black airtight plastic bags to reduce water loss through transpiration, and quickly brought to the laboratory for hydraulic analysis. In the laboratory, the branches were cut again under water. After rehydratation, segments about $2-3 \mathrm{~cm}$ long were excised under water from different branches, shaved at both ends with a razor blade, and then fitted to plastic tubes at the basal end. The segments were then perfused with filtered $(0.2 \mu \mathrm{m})$ deionized water with a pressure difference of $0.1 \mathrm{MPa}$ for $10-15 \mathrm{~min}$. This treatment eliminated any air embolisms by successive water pressurization and restored the full capacity of the xylem [25]. After removing the gas bubbles in the water, maximum conductivity (Kmax, $\mathrm{mmol} \mathrm{s}^{-1} \mathrm{~m} \mathrm{MPa}^{-1}$ ) was determined by forcing distilled water, with a pressure difference of $3.7 \mathrm{kPa}$, through each sample. The resulting flow rate $\left(\mathrm{mmol} \mathrm{s}^{-1}\right)$ was measured using an analytical balance (Sartorius). At the end of the measurement, the segment diameter was measured (m, bark not included) to determine the xylem-area-specific conductivity (Ks, mol s${ }^{-1} \mathrm{MPa}^{-1} \mathrm{~m}^{-1}$ ) which takes into account vessel diameter and the number of vessels in the samples $[12,31]$.

\subsection{Vulnerability curves}

Vulnerability curves (VCs) were established for excised wellwatered branches in which embolism was induced in a long pressure chamber $(0.4 \mathrm{~m})$, as described by Cochard et al. [3]. Air pressure in the chamber was maintained at the designated values (between 1 and $5 \mathrm{MPa}$ ) using nitrogen, until sap exudation ceased (after 10 to $60 \mathrm{~min}$, depending on the pressure applied). For each pressure treatment, the percentage loss of hydraulic conductivity (PLC) was measured for 6 to 8 randomly selected stem segments. The shape of the sigmoïd curve was characterized by three critical points, $\psi_{\text {cav }}, \psi_{50}$ and $\psi_{100}$ which indicated the water potential values that induced the start of the embolism, $50 \%$ and $100 \%$ of the maximal hydraulic conductivity, respectively. $\psi_{\text {cav }}$ and $\psi_{50}$ were measured graphically from each VC. Duplicate VCs were produced for two trees of each population.

\subsection{Statistical analysis}

Analysis of variance (ANOVA) was used to compare hydraulic conductances among individuals of each species and to compare specific conductances among species. When necessary means of specific conductances were compared with Tuckey-Kramer test. The analyses were performed with SPSS 9.0 (SPSS Inc, Chicago, IL).

\section{RESULTS}

\subsection{Hydraulic characteristics}

In all of the studied species (Fig. 1), a linear relation was observed between the maximal hydraulic conductance (Kmax) and the diameter of the stem segments used as indicated by the strong coefficients of determination obtained for every individual. The analysis of variance and the tests of TuckeyKramer indeed showed that the individuals were not significantly different among them.

Three maples of Montpellier, taken from the xeric site ("La Bastille", [16]) were compared with an individual from the arboretum of the campus where the ground is well supplied with water. Individuals of $A$. pseudoplatanus present on both 

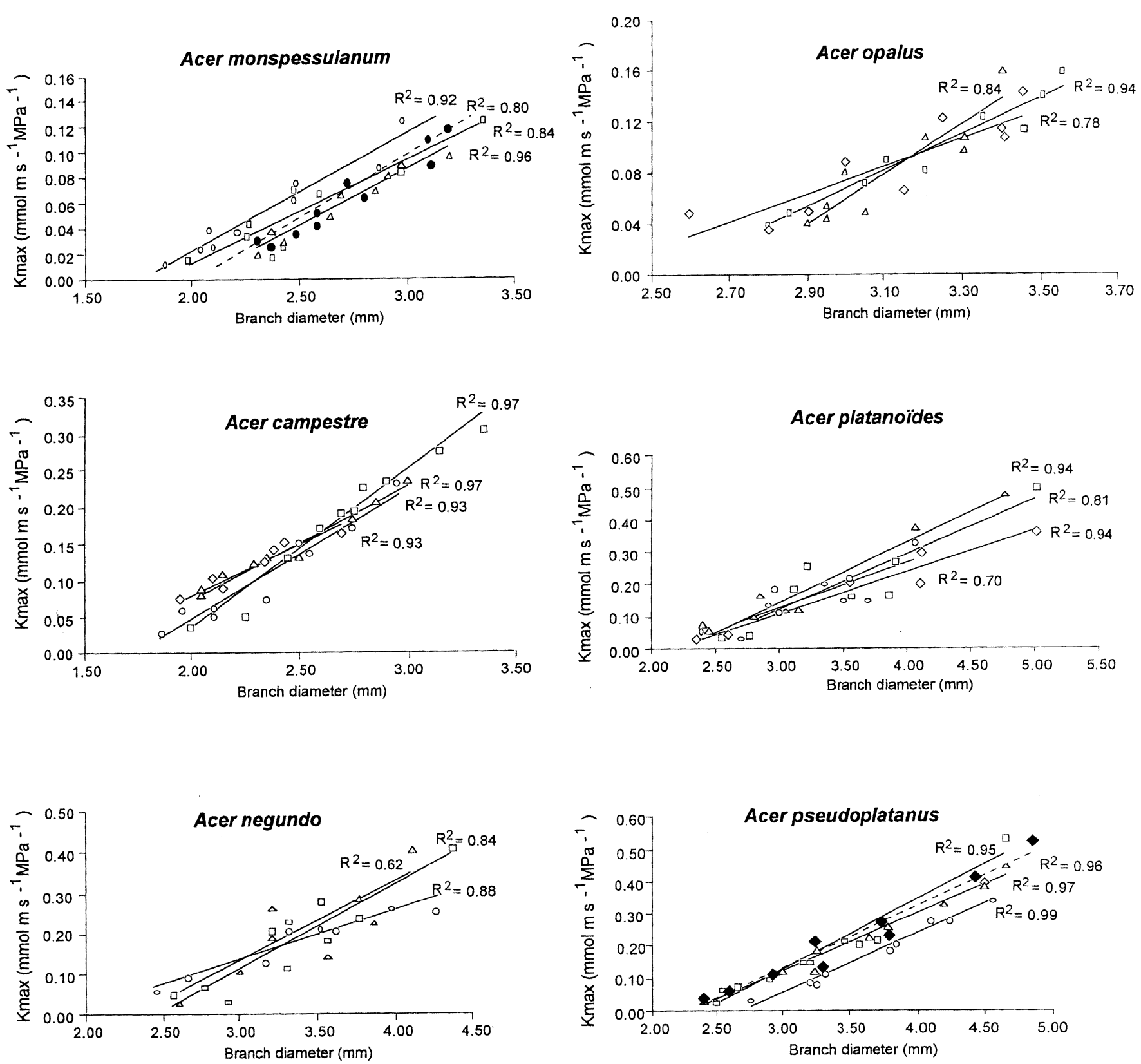

Figure 1. Xylem hydraulic conductivity (Kmax) as a function of branch diameter for maple trees. Xylem segments $2 \mathrm{~cm}$ long were excised from 1-year-old shoot internodes of adult branches. For each species, these experiments were made on three to four individual trees depicted on the graph by the different symbols. In the case of $A$. pseudoplatanus, the measurements were conducted on 3 trees originated from the wet site (arboretum) together with the tree growing under unfavorable conditions in the low mountain stand (La Bastille, closed symbols). For A. monspessulanum, three individual trees in the mountain stand were compared with a tree of the wet site (closed symbols). The linear relation between Kmax and the stem diameter is given by the regression coefficient $R^{2}$. Analysis of variance (ANOVA) was used to compare hydraulic conductances among individuals of each species.

studied sites were also compared (Fig. 1). The analyses of the variance showed, for both species, that the four individuals were not significantly different

The values of specific conductivity, for the six species of maple, are represented in Figure 2. On examination of these data, two groups of species can be distinguished: a first group, including A. negundo, A. pseudoplatanus, A. platanoides and
A. campestre, presents specific conductivities of the order of $23 \mathrm{~mol} \mathrm{~s}^{-1} \mathrm{MPa}^{-1} \mathrm{~m}^{-1}$; a second group, including A. opalus and A. monspessulanum, possess 2 times lower specific conductivities.

The statistical tests (ANOVA, $P<0.01$ ) and TuckeyKramer test show that the difference among species of both groups is highly significant. Both aforesaid groups distinguish themselves thus very sharply by their specific conductivities. 


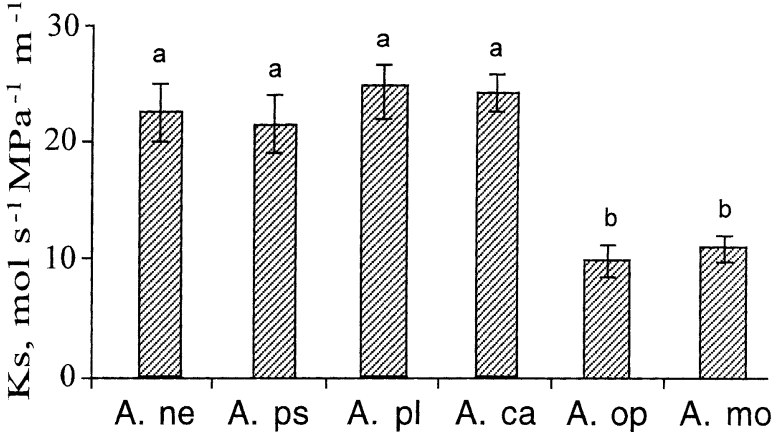

Figure 2. Comparison of the specific conductivity (Ks, $\mathrm{mol} \mathrm{s}^{-1} \mathrm{MPa}^{-1}$ $\mathrm{m}^{-1}$ ) for the six Acer species. A. ne: A. negundo; A. ps: A. pseudoplatanus; A. pl: A. platanoides; A. ca: A. campestre; A. op: A. opalus; A. m: A. monspessulanum. These experiments were carried out with four individuals trees for each species. Each value on the graph is the mean of 30 to 40 measurements. Vertical bars indicate the standard error. Values with different letters are significantly different (ANOVA, $P<0.01$ ).

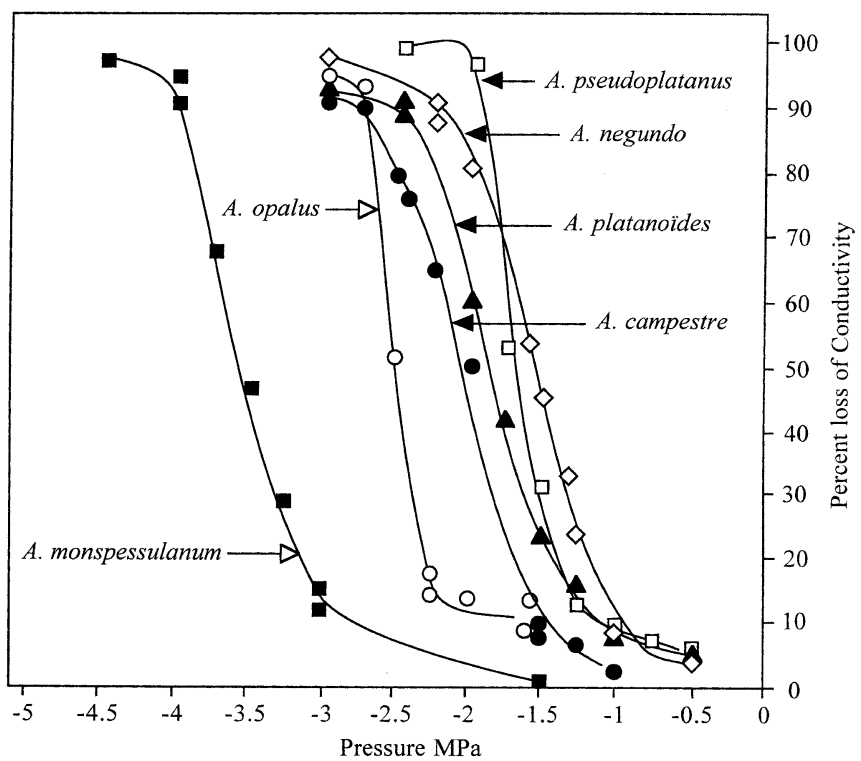

Figure 3. Comparison of the vulnerability to embolism for six species of the genus Acer. These data are obtained from two individual trees of each species, and each value on the graph is a mean of 6 to 8 replicates. The standard errors, which did not exceed $5 \%$ of the mean values, are not reported.

The least water-demanding species, implanted on relatively dry area (A. opalus and A. monspessulanum) have specific conductivities less high than the species acclimated and installed on grounds fed well with water (A. campestre, A. platanoides, A. pseudoplatanus and A. negundo).

\subsection{Vulnerability to cavitation}

The VCs of the six species of Maple are grouped together in Figure 3. It is possible to differentiate, according to their

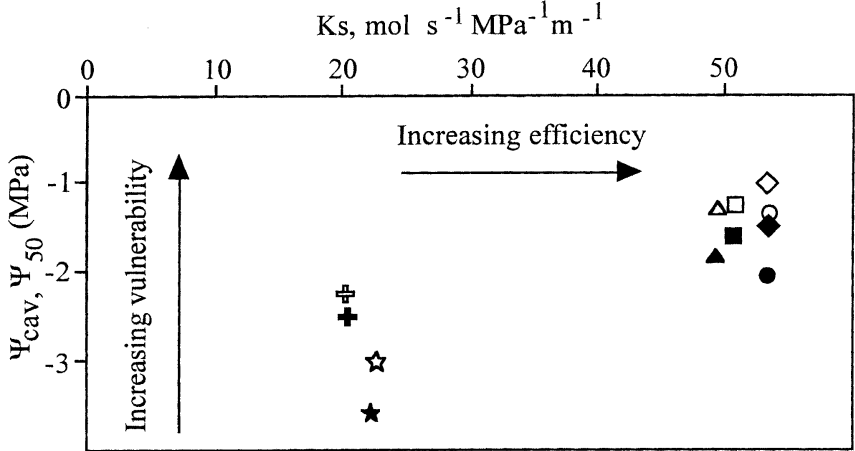

Figure 4. Xylem efficiency versus xylem vulnerability to cavitation. Xylem hydraulic efficiency is estimated by the specific hydraulic conductivity (Ks, mol s${ }^{-1} \mathrm{MPa}^{-1} \mathrm{~m}^{-1}$ ), and xylem vulnerability by the xylem water potential inducing the start of the embolism $\left(\Psi_{\text {cav }}\right.$ $\mathrm{MPa}$, open symbols) and $50 \mathrm{PLC}$ ( $\Psi_{50} \mathrm{MPa}$, black symbols).

behavior, three groups individuals. The first group comprises A. negundo, A. pseudoplatanus, A. platanoides and A. campestre with vulnerable xylem $\left(\Psi_{\text {cav }}\right.$ near $-1.2 \mathrm{MPa}$ and $\Psi_{100}$ between -2.25 and $-2.75 \mathrm{MPa}$ ). The second group is represented by $A$. monspessulanum which presents the strongest resistance to the cavitation $\left(\Psi_{\text {cav }}=-3 \mathrm{MPa} ; \Psi_{100}=-4.5 \mathrm{MPA}\right)$. A. opalus showed an intermediate curve. The major difference with the first group was that $\Psi_{\text {cav }}$ in A. opalus was more negative ( $\left.\Psi_{\text {cav }}=-2 \mathrm{MPa}\right)$ and the $\mathrm{VC}$ was steeper. These data show that when $A$. monspessulanum and A. opalus begin only to cavitate, the most sensitive species (A. campestre, A. platanoides, $A$. pseudoplatanus and $A$. negundo) are going to undergo 50 to 100 PLC. The most resistant species qualify as xerophilic or mesoxerophilic (A. monspessulanum and A. opalus). On the other hand, vulnerable the species were those on sites with mesohygric to mesic character (A. negundo, A. pseudoplatanus, A. platanoides and A. campestre).

\subsection{Hydraulic efficiency and vulnerability to cavitation}

The combined results of the specific conductivities and the vulnerability to cavitation ( $\Psi_{\text {cav }}$ and $\Psi_{50}$ ) for the six species of maple are represented in Figure 4. High hydraulic efficiency was related with vulnerable xylem. The most vulnerable species (A. negundo, A. pseudoplatanus, A. platanoides and A. campestre) were those which had the highest hydraulic efficiencies and the most resistant species (A. monspessulanum and A. opalus) had a low hydraulic conductivity indicating a trade-off between hydraulic efficiency and vulnerability to cavitation.

\section{DISCUSSION}

In woody plants, a general trend seems to be that there is a relationship between hydraulic traits and habitat preference. This is true for example among desert plants, in Angiosperm and Coniferous trees $[2,8-10,15,30]$. The data presented in this study also provide evidence of the same relationship existing among coexisting species in the highly diverse genus Acer. 
Comparison of curves representing vulnerability to cavitation show that maple species situated naturally in dry zones $(A$. monspessulanum and $A$. opalus) have a greater resistance to cavitation than those planted in sites with a good water supply (A. negundo, A. pseudoplatanus, A. platanoides, A. campestre). Furthermore, differences in specific conductivities also appear between species: i.e. A. negundo, A. pseudoplatanus, A. platanoides, $A$. campestre have high specific conductivities which are 2 times higher than A. monspessulanum and A. opalus. A relationship, thus, appears to exist between the hydraulic conductance and vulnerability to cavitation in the Acer species.

The hydraulic characteristics of branches seem to be very specific to each maple species. Indeed, when comparing species in their natural habitat (wet sites for A. pseudoplatanus, dry sites for A. monspessulanum) there is no modification in hydraulic conductivity (Fig. 1) or vulnerability to drought cavitation (data not shown) in the A. monspessulanum species cultivated at the arboretum of the campus, or in the A. pseudoplatanus species growing on the dry site of "La Bastille". This hydraulic behavior can be related to that of Fraxinus excelsior, a species that frequently occurs with maple trees. Ash trees have a broad ecological amplitude [18-20] in particular since these species acclimate to limited water availability by increasing their resistance to cavitation [13], one of the major causes of decline in the botanical species in the absence of water [5]. In contrast, Acer species are more restricted to their habitats and do not have this adaptation potential. Therefore, the survival of maples in a given biotope does not appear to be connected to acclimation capacities but rather to specific hydraulic features for each species. While cavitation resistance seems to show some phenotypic variability in ash, our study highlights species-specific differences in this trait in maple. In the case of maples, the various species distinguish themselves according to their hydraulic properties, the fruit of an ancestral evolution in biotope preference, that as conferred on each a set of acquired characteristics and ecological preferences marked for a certain type of environment.

This ecological preference is very marked according to wet zone type: one comprehends poorly why A. negundo, which already begins to cavitate at hydric potential values lower than $-1 \mathrm{MPa}$, can develop in areas where the hydric constraints can become very great. This ecological preference is less restrictive for the species adapted to the dry zones. So, by possessing hydraulic properties of plants adapted to relatively dry conditions, A. monspessulaum, for example, managed to develop without visible handicap in the arboretum of the campus (well watered area).

As has been demonstrated for several other species [4, 7, 31], our results also suggest a trade-off between xylem conductance and vulnerability to drought-induced xylem cavitation in the six species studied. The maples species that resist to cavitation possess a low hydraulic conductance, while those that are more vulnerable to cavitation present a high hydraulic conductance. The significance of this trade-off should be investigated through the study of structural/functional relationships. The mechanism by which xylem vulnerability acclimates to water stress is known to depend directly on pit pore membrane diameter, whereas hydraulic conductance is mainly related to conduit diameter $[14,27,32]$. During their development, the different tree com- ponents acclimate to the prevailing environmental conditions, and therefore develop structures that acclimate them to environmental change. Under wet conditions, plants optimize water conductance to accelerate their growth rates by developing conduits of larger diameter adapted for high water transport. In contrast, plants need to invest less in means of acquiring water for their growth in dry habitats, and therefore reduced in xylem vulnerability and in hydraulic conductivity may be advantageous in order to avoid drought-induced embolism and water transport limitations. These processes may be associated with small pores in the pit membranes and small diameters for water conducting vessel diameters. However, it is likely that other factors, including tracheid length or number and area of pits per tracheid wall, also influence xylem hydraulic properties in a complex way.

Acknowledgements: This work was supported by financial assistance from the European Community, Contract No. EVK1-CT-1999. 00031 (Proposal No EVK1-1999-00154 Flobar 2). The authors thank Nadia Barsoum, on leave from the University of Cambridge, for correcting the English, and J.P. Guichard for technical help.

\section{REFERENCES}

[1] Alder N.N., Sperry J.S., Pockman W.T., Root and stem xylem embolism, stomatal conductance, and leaf turgor in Acer grandidentatum populations along a soil moisture gradient, Oecologia 105 (1996) 293-301.

[2] Brobribb T., Hill R.S., The importance of xylem constraints in the distribution of conifer species, New. Phytol. 143 (1999) 365-372.

[3] Cochard H., Bréda N., Granier A., Aussenac G., Vulnerability to air metabolism of three European oak species (Quercus petraea (Matt) Liebl, Q. pubescens Willd, Q. robur L.), Ann. Sci. For. 49 (1992) 225-253.

[4] Cochard H., Peiffer M., Le Gall M., Granier A., Developmental control of xylem hydraulic resistances and vulnerability to embolism in Fraxinus excelsior L.: impacts on water relations, J. Exp. Bot. 48 (1997) 655-663.

[5] Cochard H., Granier A., Fonctionnement hydraulique des arbres forestiers, Rev. For. Fr. 50 (1999) 121-134.

[6] Cruiziat P., Cochard H., Améglio T., Hydraulic architecture of trees: main concepts and results, Ann. For. Sci. 59 (2002) 723-752.

[7] Domec J.C., Gartner B.L., Cavitation and storage capacity in bole xylem segments of mature and young Douglas-fir trees, Trees 15 (2001) 204-214.

[8] Froux F., Huc R., Ducrey M., Dreyer E., Xylem hydraulic efficiency versus vulnerability in seedlings of four contrasting Mediterranean tree species (Cedrus atlantica, Cupressus sempervirens, Pinus halepensis and Pinus nigra), Ann. For. Sci. 59 (2002) 409-418.

[9] Hacke U.G., Sperry J.S., Ewers B.E., Ellsworth D.S., Schafer K.V.R., Oren R., Influence of soil porosity on water use in Pinus taeda, Oecologia 124 (2000) 495-505.

[10] Kolb K.J., Sperry J.S., Differences in drought adaptation between subspecies of sagebrush, Ecology 80 (1999) 2373-2384.

[11] Kozlowski T.T., Water supply and tree growth. Part I. Water deficit, For. Abst. 43 (1982) 57-95.

[12] Lemoine D., Granier A., Cochard H., Mechanism of freeze-induced embolism in Fagus sylvatica L., Trees 13 (1999) 206-210.

[13] Lemoine D., Peltier J.P., Marigo G., Comparative studies of the water relations and the hydraulic characteristics in Faxinus excelsior, Acer pseudoplatanus and A. opalus trees under soil water contrasted conditions, Ann. For. Sci. 58 (2001) 723-731.

[14] Lemoine D., Cochard H., Granier A., Within crown variation in hydraulic architecture in beech (Fagus sylvatica L.): evidence for a stomatal control of xylem embolism, Ann. For. Sci. 59 (2002) 19-27. 
[15] Linton M.J., Sperry J.S., William D.G., Limits to water transport in Juniperus osteoperma and Pinus edulis: implications for drought tolerance and regulation of transpiration, Funct. Ecol. 12 (1998) 906-911.

[16] Manneville O., Flore et végétation dans deux stations méridionales des environs de Grenoble (Isère, France) : les sites de Comboire et de la Bastille, Saussurea 25 (1994) 155-180.

[17] Marigo G., Peltier J.P., Analysis of the diurnal change in osmotic potential in leaves of Fraxinus excelsior L., J. Exp. Bot. 47 (1996) 763-769.

[18] Marigo G., Peltier J.P., Girel J., Pautou G., Success in the demographic expansion of Fraxinus excelsior L., Trees 15 (2000) 1-13.

[19] Peltier J.P., Marigo G., Mécanismes d'ajustement et stress hydrique chez le Frêne commun, C. R. Acad. Sci. 319 (1996) 425-429.

[20] Peltier J.P., Marigo G., Drought adaptation in Fraxinus excelsior L.: physiological basis of the elastic adjustement, J. Plant. Physiol. 154 (1999) 529-535.

[21] Piñol J., Sala A., Ecological implications of xylem cavitation for several Pinaceae in Pacific Northern USA, Funct. Ecol. 14 (2000) 538-545.

[22] Pockman W.T., Sperry J.S., O’Leary J.W., Sustained and significant negative water pressure in xylem, Nature 378 (1995) 515-716.

[23] Rameau J.C., Mansion D., Dumé G., Flore Forestière Française, Guide écologique illustré, Tome 1 : plaines et collines, Ed. Dévelop. Forest., 1989.
[24] Rameau J.C., Mansion D., Dumé G., Flore Forestière Française Guide écologique illustré, Tome 2 : montagnes, Ed. Dévelop. Forest., 1993.

[25] Sperry J.S., Donnelly J.R., Tyree M.T., A method for measuring hydraulic conductivity and embolism in xylem, Plant Cell Environ. 11 (1988) 35-40.

[26] Sperry J.S., Tyree M.T., Water-stress-induced xylem embolism in three species of conifers, Plant Cell Environ. 13 (1990) 427-436.

[27]Sperry J.S., Sullivan J.E.M., Xylem embolism in response to freeze-thaw cycles and water stress in ring porous, diffuse porous, and conifer species, Plant. Physiol. 100 (1992) 605-613.

[28] Sperry J.S., Saliendra N.Z., Pockman W.T., Cochard H., Cruiziat P., Davies S.D., Ewers F.W., Tyree M.T., New evidence for large negative pressure and their measurement by the pressure chamber method, Plant Cell Environ. 19 (1996) 427-436.

[29] Tyree M.T., Sperry J.S., Do woody plants operate near the point of catastrophic xylem dysfunction caused by dynamic water stress? Answer for a model, Plant Physiol. 88 (1988) 574-580.

[30] Tyree M.T., Ewers F.W., The hydraulic architecture of trees and other woody plants, New Phytol. 119 (1991) 345-360.

[31] Tyree M.T., Davis S.D., Cochard H., Biophysical perspective of xylem evolution: is there a tradeoff of hydraulic efficiency for vulnerability to dysfunction, IAWA J. 15 (1994) 335-360.

[32] Zimmermann M.H., Xylem structure and the Ascent of sap, Springer-Verlag, New York, 1983. 